\title{
PIPELE DE LUT DIN COLECȚIA MUZEULUI NAȚIONAL DE ISTORIE A ROMÂNIEI
}

\author{
IRINA ENE
}

\author{
THE CLAY PIPES FROM THE NATIONAL HISTORY MUSEUM OF ROMANIA
}

This article presents 30 clay pipes from the collection of the National History Museum of Romania. The clay pipes have different provenance: archeological excavations, donations and acquisitions. The general criteria, used for cataloguing these objects, were established by the papers of Rebecca Robinson (Corinth and Athens) and Iuliana Costea, Aurel Stănică, Adina Ignat (Babadag, Tulcea County). The series will continue to present other such objects discovered throughout recent preventive archaeological excavations conducted by the National History Museum of Romania.

KEYWORDS: clay tobacco pipe, Oraşul de Floci, Babadag, Hârşova, $17^{\text {th }}$ century, tobacco, archaeological contexts, donations, acquisitions

CUVINTE CHEIE: pipe de lut, Oraşul de Floci, Babadag, Hârşova, secolul al XVII-lea, tutun, context arheologic, donaţii, achiziţii

Din numărul trecut al revistei Cercetări Arheologice ${ }^{1}$ am început studiul pipelor aflate în colecția Muzeului Național de Istorie a României (MNIR), prin publicarea obiectelor descoperite recent pe situl arheologic de la Orașul de Floci, cele mai multe din cercetări proprii. Articolul de față analizează, conform aceloraşi criterii științifice, pipele aflate în patrimoniul MNIR. Acestea provin din săpăturile arheologice ale instituției, dar și din donații și achiziții. Astfel, din cele 31 de pipe, șapte provin din cercetările arheologice de pe situl Orașul de Flocijudețul Ialomița, cinci de pe situl de la Babadag-județul Tulcea, două de la Hârșova-județul Constanța, cinci de la Institutul de Arheologie, șase sunt o donație a maiorului Ștefan S. Nicolae, trei sunt donație Radu Florescu, două sunt achiziții și una donație Ion Răcădeanu.

Conform registrelor muzeului, pipele sunt datate în secolele XVII, XVIII și XIX. Cu excepția celor care provin de pe situl arheologic de la Orașul de Floci, celelalte piese nu au contexte arheologice sigure. Specialiștii în domeniul cercetării acestei categorii de artefacte nu au stabilit cu certitudine datări clare în funcție de forma lor, nici pentru piesele care provin din Imperiul Otoman şi nici pentru cele din țările ce gravitau în sfera lui de influență sau din spațiul occidental. Pentru această problemă, a datării, interesante sunt relatările din secolul al XVI-lea, legate de fumat şi existența unor ateliere specializate, care, indirect, fac referire la existența acestui obicei.

În perioada interbelică a funcționat la București-Băneasa „Institutul experimental pentru cultivarea și fermentarea tutunului”, ce ținea de „Casa autonomă a monopolurilor Regatului României”, care avea un periodic numit Buletinul cultivărei și fermentărei Tutunului, sau Buletinul Tutunului. În numărul 4/1930 există un articol al lui P. Mihăescu cu referire la istoria fumatului ${ }^{2}$. Acesta amintește relatarea lui Karl Adolf Romstorfer despre cetatea Suceava, unde, printre ruine, se aflau cioburi de vase, unelte, podoabe și pipe. De asemenea, Romstorfer menționează că pe una dintre pipe era inscripționat, cu cifre arabe, anul 1571. Evident că un astfel de obiect presupune practicarea obiceiului cu ceva timp înainte. Deși cei mai mulți istorici consideră faptul că fumatul era practicat în toate mediile sociale după primul sfert al

\footnotetext{
' Ene 2013

${ }^{2}$ Mihăescu 1930
} 
secolului al XVII-lea ${ }^{3}$, în cazul pipelor descoperite în urma unor cercetări arheologice, în spațiul românesc obiceiul era atestat la sfầrșitul secolului al XVI-lea. Susținerea acestei date de debut a fumatului o regăsim și în povestiri legate de voievodul Transilvaniei, Cristofor Bathori care, în anul 1576, a primit în dar o pipă și tutun de la Constantinopol ${ }^{4}$. Cert este că, în secolul al XVII-lea negustoria cu tutun și meșteşugul realizării pipelor era foarte răspândit în spațiul românesc, deși au existat perioade în care a fost interzis în Imperiul Otoman. Spre sfârșitul secolului al XVII-lea s-au înmulțit informațiile despre tutun, fumat și pipe ${ }^{5}$.

Revenind la pipele supuse analizei noastre, înainte de toate, trebuie să supunem atenției modul în care acestea au intrat în patrimoniul muzeului. Am arătat mai sus că ele provin din donații particulare, cercetări proprii sau achiziții. Astfel, în ordinea numerelor de inventar, primul lot de două piese ${ }^{6}$ a fost donat de către Done Şerbănescu, având ca loc de proveniență orașul Hârșova și fiind datat în secolul al XVII-lea, deşi contextul arheologic este necunoscut. Despre donația lui Ion Răcădeanu ${ }^{7}$ nu se cunosc elemente legate de contextul sau locul descoperirii, și acestea fiind datate, de către autorii fișelor de evidență, în secolul al XVII-lea.

Datate tot în secolul al XVII-lea și tot fără context arheologic sunt și piesele care ne-au parvenit de la Institutul de Arheologie ${ }^{8}$. Prima pipă face parte din Colecția Mititelu, iar celelalte provin, probabil, din situri arheologice din Muntenia.

Următorul lot de pipe analizate aici îl reprezintă cele descoperite la Babadag cu ocazia cercetărilor arheologice de aici desfășurate de către specialiști din muzeu, în anul 1983. În registru aceste piese sunt trecute passim și datate în secolele XVII-XVIII ${ }^{9}$.

De la Turnu Măgurele (jud. Teleorman) provin trei pipe, donație a lui Radu Florescu, care le-a descoperit între anii din 1937 și 1940; piesele sunt datate în secolul al XVII-lea ${ }^{10}$.

Cea mai interesantă donație, prin amploare și importanta pieselor, este cea a maiorului Ştefan S. Nicolae. Actul de donație al maiorului, redactat și autentificat legal în anul 1977, impresionează prin excepționala manieră în care autorul işsi manifestă dorința de a-şi îndeplini o datorie de onoare față de Statul Român. Prin el, donatorul se înscrie în categoria oamenilor care înțeleg la justa valoare importanța artefactelor în construirea și perpetuarea istoriei, atât locale, cât și naționale, demonstrând calități deosebite în ceea ce privește grija față de patrimoniu, care are rolul de a sta mărturie asupra trecutului. Cunoaștem astfel faptul că este un pensionar cu gradul I de invaliditate din Costești (jud. Argeș), fiind rănit în luptele de la Turtucaia, din 23 august 1916. De asemenea, actul menționează că, având 23 de ani, a luptat corp la corp la baionetă pentru apărarea şi întregirea neamului, iar la 86 de ani, momentul donației, are „o mare obligație de îndeplini” pe care o face cu convingerea că, prin donația colecției sale, contribuie la sporirea documentelor istorice necesare limpezirii unor perioade din istoria românească.

Colecția sa cuprinde monede și obiecte arheologice pe care le-a achiziționat între cele două războaie mondiale (1919-1940) din orașul Constanța și cele patru județe ale Dobrogei de atunci: Constanța, Tulcea, Caliacra, Durostor și în sudul Basarabiei, Cetatea Albă. Pipele, în număr de șase, sunt datate în secolul al XVIII-lea ${ }^{11}$.

În patrimoniul MNIR există și două pipe care au fost achiziționate de la Ionică Sentes, datate în secolele XVIII-XIX ${ }^{12}$.

În ceea ce privește piesele cu contexte arheologice certe, analiza are în vedere un lot descoperit în campania arheologică din anul 1987 de la Orașul de Floci. Este vorba despre un număr de 27 de pipe întregi și fragmente ${ }^{13}$, din care au fost introduse în patrimoniul muzeului

\footnotetext{
3 Ene 2013, 198

4 Mihăescu 1930, 533

5 Ene 2013

${ }^{6}$ Inv. MNIR. 74123 și 74124

Inv. MNIR. 74845

${ }^{8}$ Inv. MNIR: $117811,120217,120218,120181,120180$

9 Inv. MNIR: 176041, 176043, 176044, 176045

${ }^{10}$ Inv. MNIR: $301574,301575,301576$

${ }^{11}$ Inv. MNIR: $131153,131154,131155,131156,131157,131158$

${ }^{12}$ Inv. MNIR: 317522,317523

${ }^{13}$ Chițescuet alii $1992,100-102$
} 
un număr de șase ${ }^{14}$. Între piesele provenite din situl arheologic mai există o pipă descoperită în stratul de cultură, dintr-o campanie ulterioară (MNIR, inv. 304693).

Contextul arheologic datează aceste obiecte în secolul al XVII-lea. Ele au fost descoperite pe podeaua unui atelier de prelucrat osul, cunoscut în bibliografie ca drept Atelierul nr. $5^{15}$, care suprapunea la rândul lui o locuință cu pivniță. Alături de resturi osteologice, obiecte din os în diferite stadii de prelucrare, cuțite din fier și podoabe au fost descoperite pe podeaua complexului arheologic și două monede: o monedă otomană din secolul al XVII-lea și un fals din bronz, bătut la Suceava după un solidus Carol Gustav pentru Riga în 1660. Situația stratigrafică și datarea locuinței cu pivniță, care este suprapusă de atelier, cu monedă în secolul al XVI-lea, permite situarea acestuia din urmă cu certitudine în a doua jumătate a secolului al XVII-lea ${ }^{16}$. De asemenea, autori ai săpăturii arheologice, au considerat că atelierul este unul complex, aici fiind prelucrate, nu numai obiectele din os, ci și celelalte podoabe (inele, nasturi din bronz, argint și argint aurit).

Catalogul ce completează acest studiu urmărește tipologia generală preluată din lucrarea doamnei Rebecca Robinson ${ }^{17}$, care stabilește o clasificare a pipelor descoperite la Corint și Atena în funcție de forma găvanului, utilizată și de autorii articolului dedicat pipelor de la Babadag ${ }^{18}$. De asemenea, aceleaşi criterii le-am utilizat în analiza pipelor de la Orașul de Floci, menționat anterior. Considerăm necesară trecerea în revistă a celor trei mari categorii, în funcție de care pot fi grupate pipele de față. Astfel, prima grupă, A, este reprezentată de pipele care au găvanul rotund, piciorul scurt, inelul bine evidențiat, simple sau amplu decorate. Grupa B cuprinde pipele care au găvanul în formă de disc. A treia categorie, C, cuprinde pipele cu găvanul în formă de clopot sau polifațetat, gamba evidențiată şi inelul de formă octogonală.

Din punct de vedere tipologic pot fi încadrate Grupei A 20 de piese, Grupei B șapte și Grupei $\mathrm{C}$ trei. Din punct de vedere cronologic, șapte sunt datate cu siguranță în secolul al XVII-lea, provenind din cercetarea arheologică de la Orașul de Floci.

\footnotetext{
${ }^{14}$ Inv. MNIR: 304693, 304703, 304704, 304705, 304706, 304707, 304709

${ }^{15}$ Chițescuet alii 1992,100

${ }^{16}$ Chițescuet alii 1992, 102

${ }^{17}$ Robinson 1985

${ }^{18}$ Costea, Stănică, Ignat 2007
} 
CATALOG $^{19}$

1. Pipă, inv. MNIR74123; $\mathrm{L}=5,30 \mathrm{~cm}, \mathrm{H}=5 \mathrm{~cm}$, $\mathrm{Dg}=3,10 \mathrm{~cm} ; \mathrm{Di}=2,10 \mathrm{~cm}$. Lucrată din caolin de culoare crem, găvan ${ }^{20}$ inalt cilindric, bordură cu marginea teșită oblic, gambă scurtă, simplă, cu inelul în formă de manşon. Datare: secolul al XVII-lea; grupa A (PI. I/1)

2. Pipă, inv. MNIR 74124; $\mathrm{L}=5 \mathrm{~cm} ; \mathrm{H}=5,40 \mathrm{~m}$; $\mathrm{Dg}=2 \mathrm{~cm} ; \mathrm{Di}=2,50 \mathrm{~cm}$. Lucrată din caolin de culoare crem, găvan înalt cilindric, cu marginea teşită oblic, gamba scurtă decorată pe o parte cu o rozetă şi inelul sub forma unui manşon. Datare: secolul al XVII-lea; grupa A (PI. I/2)

3. Pipă, inv. MNIR74845; $\mathrm{L}=5,30 \mathrm{~cm} ; \mathrm{H}=2,80$ $\mathrm{cm} ; \mathrm{Dg}=2,70 \mathrm{~cm} ; \mathrm{Di}=1,70 \mathrm{~cm}$. Lucrată din caolin de culoare crem cu găvanul în formă de disc aplatizat, bordura înaltă, gamba simplă, scurtă care se îngroaşă în formă de inel. Găvanul are bordura spartă, iar decorul este reprezentat de un registru delimitat în partea superioară de o linie excizată din care pornesc linii paralele verticale pe toată circumferința. Gamba, decorată cu o linie excizată la baza inelului, se unește cu găvanul în forma literei „V”. Datare: secolul al XVII-lea; grupa A, (Pl. I/3).

4. Pipă, inv. MNIR $117811 ; \mathrm{L}=5,40 \mathrm{~m} ; \mathrm{H}=3,90$ $\mathrm{cm} ; \mathrm{Dg}=3,30 \mathrm{~cm} ; \mathrm{Di}=2 \mathrm{~cm}$. Lucrată din ceramică roșiatică cu găvanul rotund, bordura înaltă, uşor evazată, gamba scurtă, care se termină spre găvan în forma literei „V”. Pe suprafaţa exterioară a bordurii este delimitat un registru cu două linii subțiri, circulare în partea inferioară, fiind decorat $\mathrm{cu}$ linii verticale, fin incizate, despărţite de linii verticale, punctate, trasate cu rotiţa. Inelul prezintă un decor din linii scurte incizate, paralele. Piesa are găvanul spart pe jumătate şi prezintă ardere secundară. Datare: secolele XVI-XVII; grupa A (PI. I/4)

5. Pipă (fragmentară), inv. MNIR 120180; L = 5 $\mathrm{cm} ; \mathrm{Di}=28 \mathrm{~cm}$. Lucrată din ceramică roșiatică. Se păstrează doar gamba, lustruită și evazată. Sub inel decorul este compus din două linii paralele trasate cu rotiţa. Între acest decor şi marginea inelului este imprimat un însemn otoman, înscris într-un cerc, ca o ştampilă. Gamba se uneşte cu găvanul printr-un decor în forma literei „V”. Datare: secolele XVI-XVII; grupa A (PI. 1/5).

6. Pipă, inv. MNIR $120181 ; \mathrm{L}=4,50 \mathrm{~cm} ; \mathrm{H}=$ $3,20 \mathrm{~cm} ; \mathrm{Dg}=2,30 \mathrm{~cm} ; \mathrm{Di}=2,10 \mathrm{~cm}$. Lucrată din ceramică cenuşie, fină, bine frământată cu ardere reducătoare. Găvanul, rupt, este scurt, cilindric decorat cu caneluri care se prelungesc și pe gambă până la inelul profilat. Datare: secolul al XVII-lea; grupa A (PI. I/6).

\footnotetext{
${ }^{19}$ Abrevieri: $\mathrm{L}=$ lungime; $\mathrm{H}$ = înălţime; $\mathrm{Dg}=$ diametru găvan; $\mathrm{Di}=$ diametru inel.

${ }^{20}$ Termenii ce defines elementele componente ale pipei au fost preluate din Costea, Stânică, Ignat 2007
}

7. Pipă, inv. MNIR 120217; $\mathrm{L}=5 \mathrm{~cm} ; \mathrm{H}=2,30$ $\mathrm{cm} ; \mathrm{Dg}=3 \mathrm{~cm}$. Lucrată din ceramică roșiatică, cu găvanul rotund, bordura spartă în partea superioară, gamba foarte scurtă şi inelul în formă de inel. Găvanul este decorat pe suprafaţa exterioară cu caneluri verticale, iar manşonul inelului cu caneluri oblice. Piesa are smalț verde închis. Jumătate din gambă şi din inel lipsesc. Datare: secolele XVI-XVII; grupa A (PI. I/7)

8. Pipă (fragmentară), inv. MNIR 120218; H = $3,80 \mathrm{~cm} ; \mathrm{Dg}=3 \mathrm{~cm}$. Lucrată din caolin din care se păstrează doar găvanul rotund, decorat cu caneluri verticale înscrise într-un registru delimitat la baza bordurii de o linie incizată circulară. Din bordură înaltă, cilindrică se mai păstrează pe o porţiune, o linie fină, lucrată cu rotița dințată. Gamba se unește cu găvanul printrun decor în forma literei „V”. Bordura este spartă şi gamba lipseşte. Datare: secolele XVI-XVII; grupa A (PI. I/8).

9. Pipă, inv. MNIR 131153; $\mathrm{L}=5 \mathrm{~cm} ; \mathrm{H}=2,80$ $\mathrm{cm} ; \mathrm{Dg}=3,40 \mathrm{~cm} ; \mathrm{Di}=2,20 \mathrm{~cm}$. Lucrată din caolin cu găvanul rotund, separat de bordura scurtă teşită, spartă, prin două caneluri circulare. Suprafaţa exterioară a găvanului este decorată cu striuri verticale paralele. Gamba este scurtă şi prezintă o creastă mediană perforată şi un manşon decorat cu striuri oblice înaintea inelului de care se separă printr-o linie excizată circulară. Gamba se unește cu găvanul printr-un decor în forma literei „V”.Datare: secolul al XVIII-lea; grupa A (PI. I/9).

10. Pipă (fragmentară), inv. MNIR 131154; $L=$ $5,60 \mathrm{~cm} ; \mathrm{Dg}=3,10 \mathrm{~cm} ; \mathrm{Di}=25 \mathrm{~cm}$. lucrată din ceramică roşiatică cu găvanul în formă de disc aplatizat şi lobat $(7$ lobi). La baza bordurii prezintă un decor format din linii scurte incizate vertical, apoi trei linii paralele incizate orizontal şi una în val, trasate cu rotița. Gamba tronconică se termină cu inelul reliefat. Decorul gambei porneşte de la baza inelului sub forma unui brâu format din linii scurte verticale incizate, înscrise între 2 linii subţiri, orizontale. Inelul este decorat cu rotița. Gamba se unește cu găvanul printr-un decor în forma literei „V”. Marginea găvanului şi o parte din peretele bordurii lipsesc. Datare: secolul al XVIII-lea; grupa B (PI. 1/10).

11. Pipă, inv. MNIR 131155; $\mathrm{L}=5,40 \mathrm{~cm} ; \mathrm{H}=$ $2,60 \mathrm{~cm} ; \mathrm{Dg}=3 \mathrm{~cm} ; \mathrm{Di}=1,80 \mathrm{~cm}$. Lucrată din ceramică cenuşie, cu găvanul în formă de disc, format din 7 lobi pe partea superioară; pe fiecare lob sunt imprimate cercuri cu monograme. Fiecare lob se continuă cu 7 caneluri în partea posterioară. Gamba este scurtă decorată cu caneluri şi separată cu un manşon de inel. Bordura este scurtă şi ruptă. Datare: secolul al XVIII-lea; grupa B (PI. II/11).

12. Pipă, inv. MNIR $131156 ; \mathrm{L}=4,90 \mathrm{~cm} ; \mathrm{H}=$ $1,50 \mathrm{~cm} ; \mathrm{Dg}=3,40 \mathrm{~cm} ; \mathrm{Di}=1,90 \mathrm{~cm}$. Lucrată din 
ceramică roşiatică,cu găvanul în formă de disc puţin înalt decorat pe suprafaţa lui, în jurul bordurii cu striuri dispuse radial. Găvanul se delimitează de bordură printr-o linie lucrată cu rotița zimțată. Gamba scurtă se prelungește pe partea posterioară a găvanului în forma literei ,V”. Aceasta este decorată cu două linii concentrice excizate lucrate cu rotița. Inelul este de forma unui manşon decorat cu romburi realizate cu rotiţa. Datare: secolul al XVIII-lea; grupa B (PI. II/12).

13. Pipă, inv. MNIR 131157; $\mathrm{L}=5,80 \mathrm{~cm} ; \mathrm{H}=$ $3,30 \mathrm{~cm} ; \mathrm{Dg}=3,10 \mathrm{~cm} ; \mathrm{Di}=1,90 \mathrm{~cm}$. Lucrată din ceramică de culoare neagră cu găvanul sub formă de disc aplatizat şi lobat (5 lobi). Bordura este înaltă, uşor evazată. Inelul este de forma unui manşon reliefat format din semiove. Bordura este ruptă parţial. Datare: secolul al XVIII-lea; grupa B (Pl. II/13).

14. Pipă, inv. MNIR $131158 ; \mathrm{L}=4,60 \mathrm{~cm} ; \mathrm{H}=2,10$ $\mathrm{cm} ; \mathrm{Dg}=2,50 \mathrm{~cm}$. Lucrată din ceramică cenuşie, cu găvanul de forma unui disc, puţin adânc, este poziționat oblic faţă de gambă. Aceasta prezintă şapte caneluri în interiorul cărora se află decorată câte o frunză lucrată cu rotița și 2 şiruri de linii realizate cu rotiţa. Între aceste două şiruri se delimitează un registru în care sunt excizate litere arabe sub forma unei inscripții. Bordura şi inelul sunt rupte. Datare: secolul al XVIII-lea; grupa A (Pl. II/14).

15. Pipă, inv. MNIR $176041 ; \mathrm{L}=5,80 \mathrm{~cm} ; \mathrm{H}=$ $4,70 \mathrm{~cm} ; \mathrm{Dg}=3,10 \mathrm{~cm} ; \mathrm{Di}=2,70 \mathrm{~cm}$. Lucrată din ceramică roșiatică, fină, cu firnis roşu. Găvanul este înalt, cilindric în formă de trompetă şi bordura evazată spre exterior cu marginea rotunjită. Gamba scurtă este decorată aproape de inel cu două șiruri de incizii fine făcute cu rotiţa și cu o stampilă circulară pe o parte. Gamba se unește în partea posterioară a găvanului în forma literei „V”. O a treia linie decorează inelul teşit orizontal. Datare: secolul al XVII-lea; grupa C (PI. II/15).

16. Pipă, inv. MNIR 176042, $L=5,10 \mathrm{~cm} ; H=4,20$ $\mathrm{cm} ; \mathrm{Dg}=2,90 \mathrm{~cm} ; \mathrm{Di}=1,80 \mathrm{~cm}$. Lucrată din ceramică cărămizie, fină. Gãvanul este înalt, cilindric, gamba scurtă și bordura dreaptă. Găvanul este decorat la mijlocul înālțimii sale cu două șiruri de linii punctate lucrate cu rotița. În partea inferioară acestor linii decorul găvanului este compus din linii verticale paralele incizate. Întreg decorul este lucrat firav, în anume porțiuni fiind șters. Gamba se unește în partea posterioară a găvanului în forma literei ,V”. Inelul se uneşte de gambă printr-un manşon teșit orizontal. Datare: secolul al XVII-lea; grupa A (PI. II/16).

17. Fragment de pipă, inv. MNIR 176043; Dg = $4,60 \mathrm{~cm}$. Lucrată din ceramică roșiatică, lustruită din care se păstrează doar găvanul în formă de disc cu marginea zimţată şi decorată cu un şir de incizii realizate cu rotiţa. Datare: secolul al XVIIlea; grupa B (PI. IL/17).
18. Fragment de pipă, inv. MNIR 176044; L = $4,60 \mathrm{~cm} ; \mathrm{Di}=2 \mathrm{~cm}$. Lucrată din ceramică roșiatică lustruită din care se păstrează doar gamba scurtă şi o parte din inelul profilat şi decorat cu rotița. Gamba este despărțită de inel printr-o linie excizată și este decorată cu o pasăre şi o monogramă înscrisă într-un cerc, unindu-se cu găvanul în forma literei „V”. Datare: secolul al XVII-lea; grupa A (PI. II/18).

19. Fragment de pipă, inv. MNIR 176045; L = $5,50 \mathrm{~cm} ; \mathrm{H}=2,20 \mathrm{~cm} ; \mathrm{Dg}=3,40 \mathrm{~cm} ; \mathrm{Di}=2,30$ $\mathrm{cm}$. Lucratã din ceramică roșiatică, cu ardere oxidantă din care se păstrează jumătate din găvan, gambă şi inel. Gamba este scurtă iar inelul în formă de manșon este decorat cu linii incizate, paralele verticale. Gamba se uneşte cu găvan în forma literei „V”. Găvanul prezintă în partea superioară un decor format dintr-o linie incizată urmată de un registru floral închis de o linie incizată lucrată cu rotița. Datare: secolul al XVIIlea; grupa A (PI. II/19).

20. Fragment de pipă, inv. MNIR 301574; H = $3,60 \mathrm{~cm} ; \mathrm{Dg}=3,50 \mathrm{~cm}$. Lucrată din ceramică roşiatică, cu găvanul rotund decorat pe suprafaţa exterioară cu striuri verticale. Gamba se unește cu găvan în forma literei „V”. Se păstrează doar găvanul și începutul gambei. Datare: secolul al XVII-lea; grupa A (PI. II/20).

21. Fragment de pipă, inv. MNIR $301575 ; \mathrm{L}=4$ $\mathrm{cm} ; \mathrm{H}=3,20 \mathrm{~cm} ; \mathrm{Dg}=3,20 \mathrm{~cm}$. Lucrată din ceramică roșiatică, cu găvanul rotund. $\mathrm{Se}$ păstrează o mică parte din gambă și găvanul rotund cu bordura spartă. Gamba se uneşte cu găvanul printr-un decor în forma literei „V" lucrat cu rotița. Se păstrează doar găvanul. Datare: secolul al XVII-lea; grupa A (PI. II/21).

22. Fragment de pipă, inv. MNIR 301576; L = $3,40 \mathrm{~cm} ; H=4,10 \mathrm{~cm}$. Lucrată din ceramică roşiatică, cu găvanul în formă de trompetă. Se păstrează doar o porțiune din găvan și bordură. Datare: secolul al XVII-lea; grupa C (PI. III/22).

23. Pipã, inv. MNIR 304693; $\mathrm{L}=5 \mathrm{~cm} ; \mathrm{H}=2,60$ $\mathrm{cm} ; \mathrm{Dg}=3 \mathrm{~cm} ; \mathrm{Di}=1,70 \mathrm{~cm}$. Lucrată din ceramică de culoare cenuşie cu găvanul rotund, bordura ruptă, gamba decorată cu un manşon lângă inelul decorat cu linii oblice paralele executate cu rotiţa. Suprafaţa exterioară a găvanului este decoratā pe linia diametrului maxim cu linii oblice paralele executate cu rotiţa. Gamba se unește cu găvan în forma literei "V". Datare: secolul al XVII-lea; grupa A (PI. III/23).

24. Pipă, inv. MNIR 304703; $\mathrm{L}=5,30 \mathrm{~cm} ; \mathrm{H}=$ $2,60 \mathrm{~cm} ; \mathrm{Dg}=2,90 \mathrm{~cm} ; \mathrm{Di}=1,60 \mathrm{~cm}$. Lucrată din ceramică roşiatică, cu găvanul rotund, bordura ruptă, gamba scurtă decorată cu un manşon lat lângă inel. Suprafạ̧a gambei şi a manşonului sunt decorate cu caneluri oblice, iar suprafaţa exterioară a găvanului cu proeminenţe. Întregul exemplar este acoperit cu smalţ de culoare verde- 
oliv. Datare: secolul al XVII-lea; grupa A (PI. III/24).

25. Pipă, inv. MNIR 304704; $\mathrm{L}=5,30 \mathrm{~cm} ; \mathrm{H}=$ $2,20 \mathrm{~cm} ; \mathrm{Dg}=2,90 \mathrm{~cm} ; \mathrm{Di}=1,80 \mathrm{~cm}$. Lucrată din ceramică de culoare cenușie, cu găvanul în formă de disc, lobat (7 lobi). Fiecare lob se continuă cu 7 caneluri în partea posterioară. Gamba este scurtă decorată cu caneluri şi separată cu un manşon de inelul profilat. Bordura este scurtă și ruptă. Pe fiecare lob al găvanului este incizat un motiv decorativ (,Steaua lui David”) înscris intrun cerc. Datare: secolul al XVII-lea; grupa B (PI. III/25).

26. Pipã, inv. MNIR 304705; $\mathrm{L}=4,50 \mathrm{~cm} ; \mathrm{H}=$ $3,60 \mathrm{~cm} ; \mathrm{Dg}=2,40 \mathrm{~cm} ; \mathrm{Di}=1,80 \mathrm{~cm}$. Lucrată din caolin cu găvanul cilindric, în formă de trompetă, gamba scurtă mărginită de un inel teşit orizontal şi decorată cu o muchie profilată. Găvanul este decorat pe suprafaţa exterioară cu fascicole de 3 striuri verticale dispuse la distanţe egale. Prezintă urme de ardere secundară pe peretele interior al găvanului. Datare: secolul al XVII-lea; grupa C (PI. III/26).

27. Fragment de pipă, inv. MNIR 304706; L = $3,20 \mathrm{~cm} ; \mathrm{H}=4,20 \mathrm{~cm} ; \mathrm{Dg}=2,50 \mathrm{~cm}$. Lucrată din ceramică roşiatică, cu găvanul cilindric, decorat pe suprafaţa exterioară cu caneluri verticale și un inel care o desparte de bordura înaltă cilindrică, cu marginea rotunjită. Gamba foarte scurtă, inelul lipsește. Datare: secolul al XVII-lea; grupa B (PI. III/27).

28. Pipă, inv. MNIR $304707 ; \mathrm{L}=5,20 \mathrm{~cm} ; \mathrm{H}=$ $3,40 \mathrm{~cm} ; \mathrm{Dg}=3,30 \mathrm{~cm} ; \mathrm{Di}=2,40 \mathrm{~cm}$. Lucrată din ceramică de culoare roșiatică, lustruită, cu găvanul rotund, bordura spartă, gamba scurtă şi un inel teşit orizontal, decorat cu rotiţa. Găvanul este decorat pe suprafaţa exterioară cu striuri verticale, fiind delimitat de bordură printr-o linie incizată lucrată cu rotiţa. Gamba se uneşte cu găvanul printr-un decor în forma literei „V", lucrat cu rotiţa. Datare: secolul al XVII-lea; grupa A (PI. III/28).

29. Fragment de pipă, inv. MNIR 304709; H = $3,80 \mathrm{~cm}$. Lucrată din ceramică de culoare neagră, lustruită, cu găvanul rotund și bordura înaltă cilindrică fragment. Gamba se unește cu găvanul printr-un decor în forma literei „V”. Se păstrează doar gávanul şi bordura cu peretele spart. Datare: secolul al XVII-lea; grupa A (Pl. III/29).

30. Pipă, inv. MNIR $317522 ; \mathrm{L}=4,50 \mathrm{~cm} ; \mathrm{H}=$ $2,50 \mathrm{~cm} ; \mathrm{Dg}=2,30 \mathrm{~cm} ; \mathrm{Di}=2,10 \mathrm{~cm}$. Lucrată din ceramică cenuşie, cu găvanul rotund, scurt şi bordura cilindrică. Gamba decorată în exterior cu o palmetă care se prelungește pe partea posterioară a găvanului. Inelul gambei este teşit orizontal şi decorat la bază cu o linie subţire incizatã. Datare: secolele XVIII-XIX; grupa A (PI. III/30).

31. Pipă, inv. MNIR 317523; $\mathrm{L}=4,50 \mathrm{~cm} ; \mathrm{H}=$ $2,6 \mathrm{~cm} ; \mathrm{Dg}=2,70 \mathrm{~cm} ; \mathrm{Di}=1,50 \mathrm{~cm}$. Lucrată din caolin, cu găvanul rotund, cu bordura spartă. Găvanul este decorat pe suprafaţa exterioară cu o linie în zigzag incizată. Bordura se delimitează de găvan prin două linii circulare incizate. Gamba este scurtă, spartă, se păstrează doar un sfert din inelul profilat. Datare: secolele XVIII-XIX; grupa A (Pl. III/31).

\section{BIBLIOGRAFIE}

Chițescu et alii 1992

Costea, Stănică, Ignat 2007

Ene 2013

Robinson 1985

Mihăescu 1930

Foto: George Nica
L. Chițescu, Anca Păunescu, Gh. Matei, Elena Rența, V. Nițulescu, Cercetările arheologice de la Piua Petri (Orașul de Floci) comuna Giurgeni, jud. Ialomița, CA, IX, 1992, p. 97-104

Iuliana Costea, A. Stănică, Adina Ignat, Pipele de lut descoperite la Babadag, Peuce, SN, V, 2007, p. 335-362

Irina Ene, Pipele de lut descoperite la Oraşul de Floci, comuna Giurgeni, jud. Ialomița, $C A, X X, 2013$, p. 197-206

Rebecca C. W. Robinson, Tobacco pipe of Corint hand of the Athenian Agora, American School of Classical Studies at Athens, 54, 2, p. 149-203 P. Mihăescu, Câteva note istorice asupra deprinderii de a fuma în țările locuite de români, Buletinul tutunului, 4, 1930, p. 532-545 


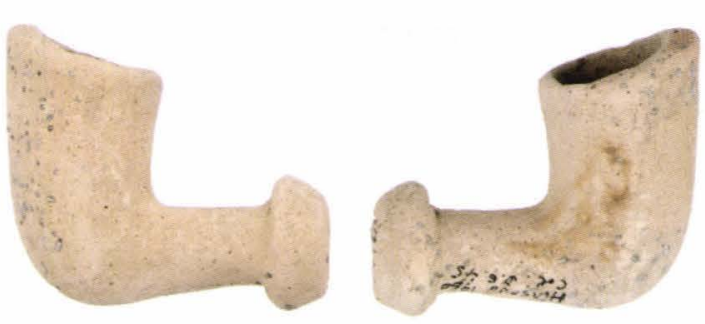

1.
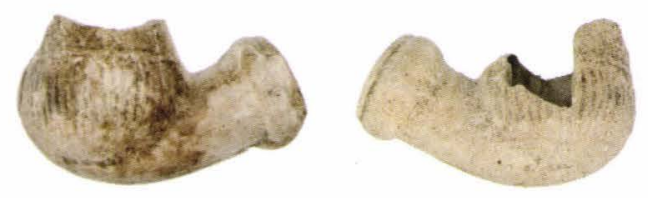

3.

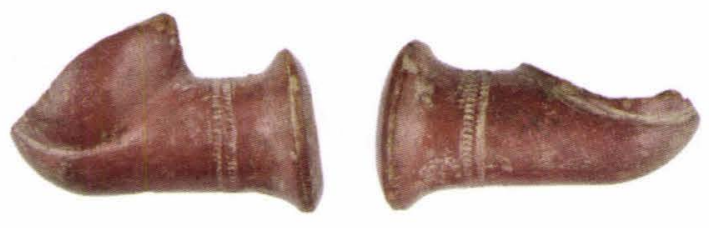

5.
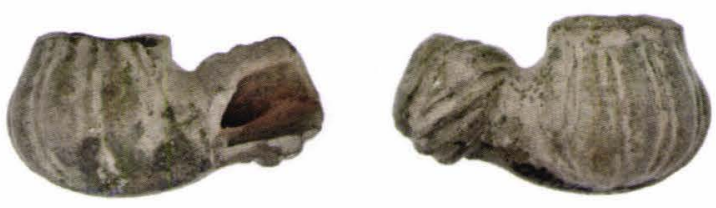

7.
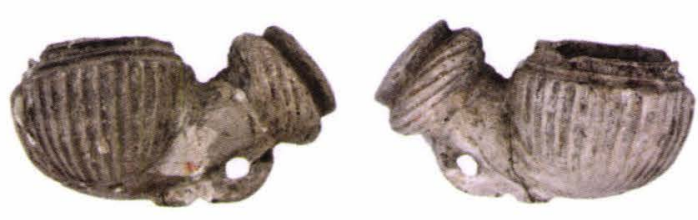

9.

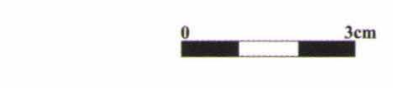

2.

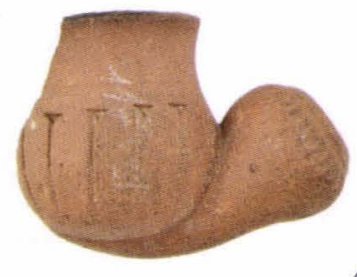

4.
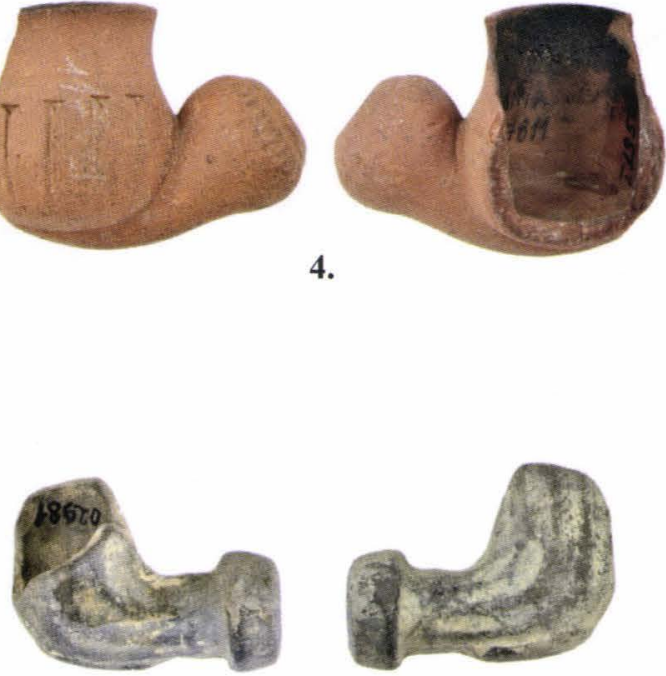

6.
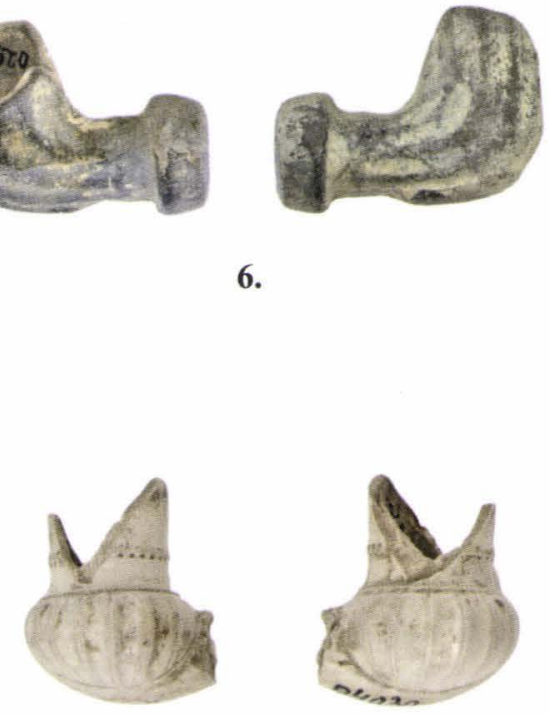

8.
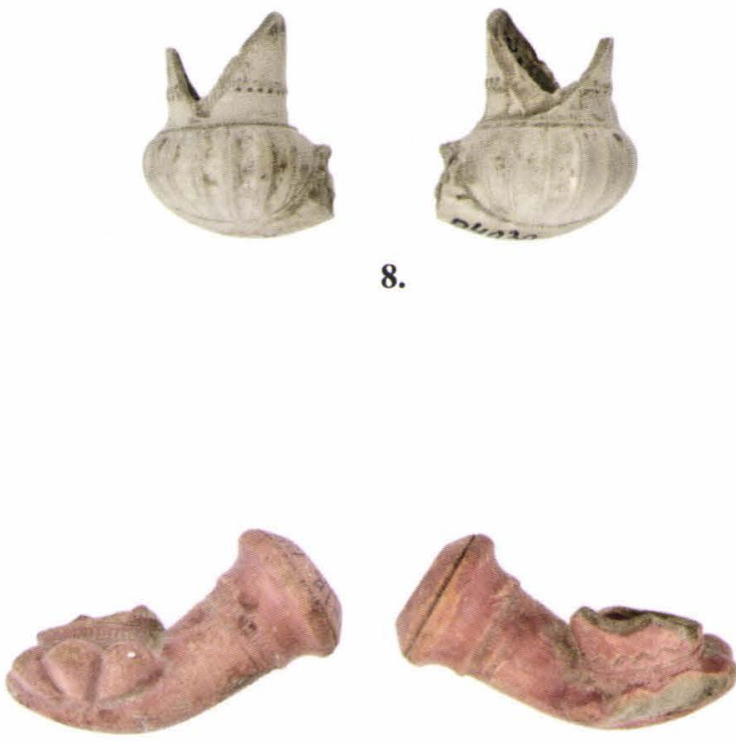

10.

Pipe din colecția MNIR, nr. cat. 1-10

PI. I 


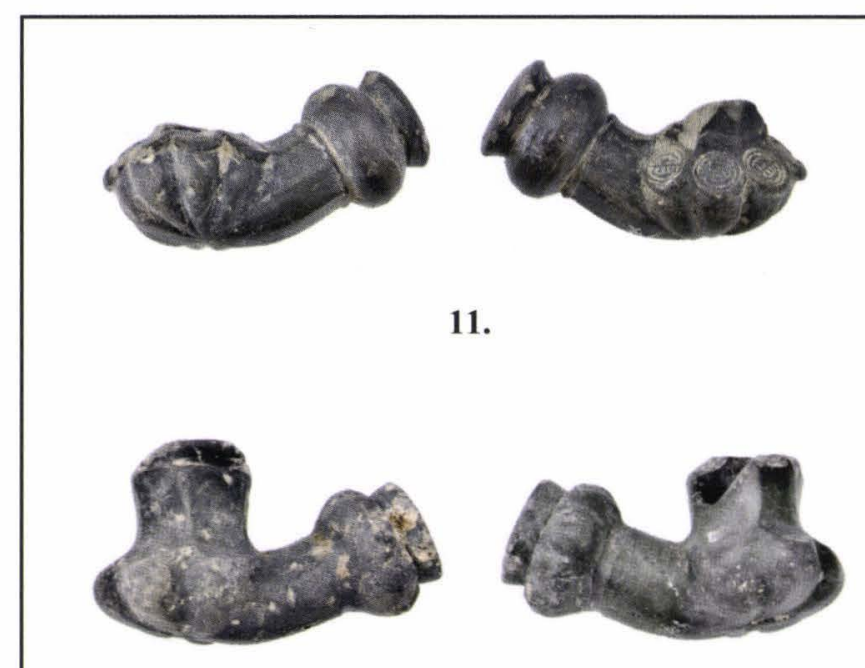

13.

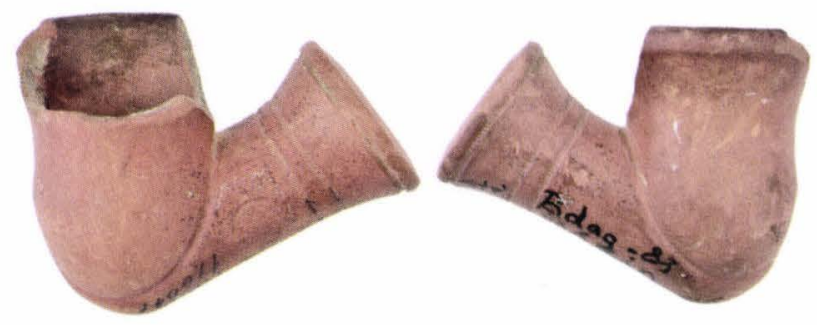

15.

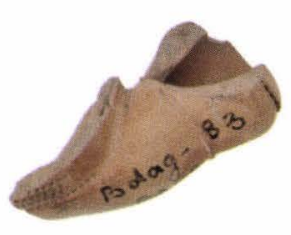

18.
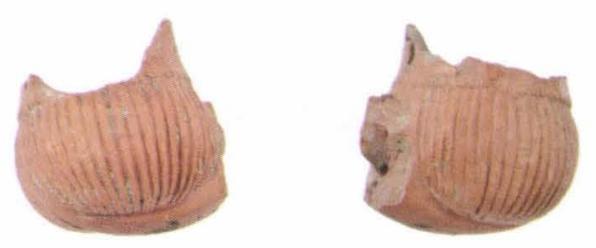

20.

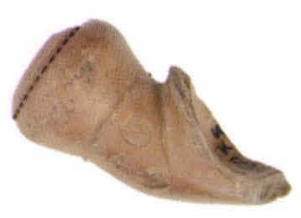

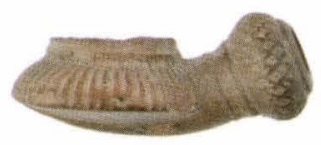

12.

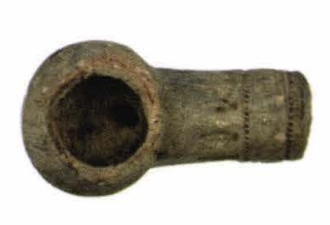

14.

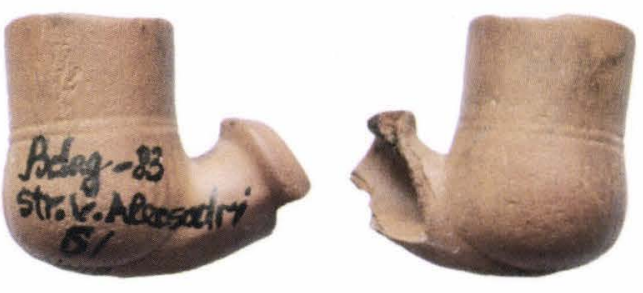

16.

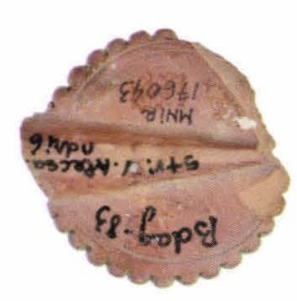

17.
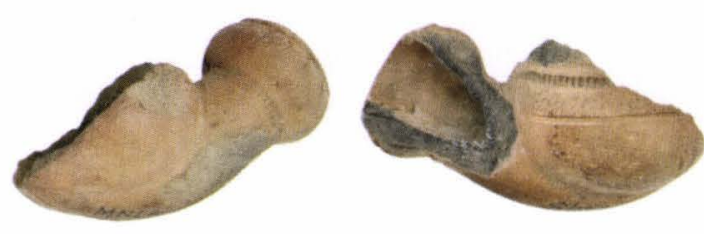

19.
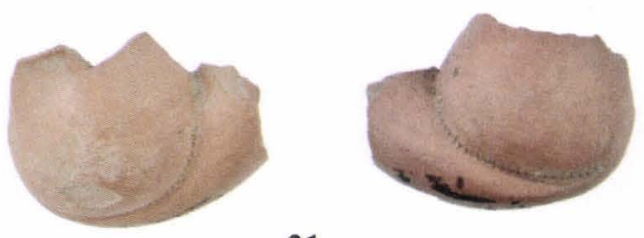

21.

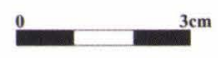

Pipe din colecția MNIR, nr. cat. 11-21

PI. II 

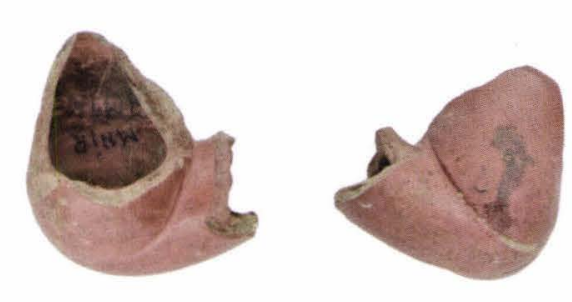

22.
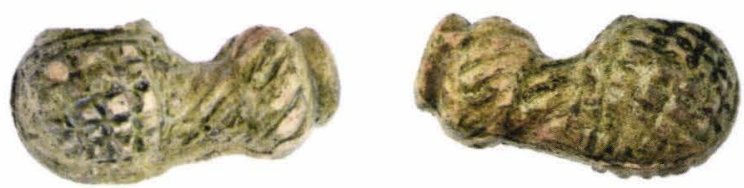

24.
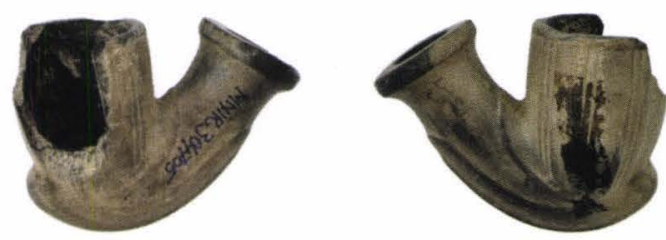

26.
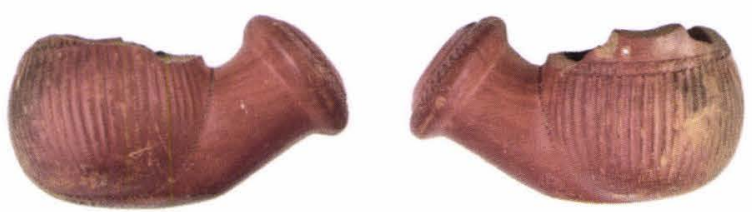

28.
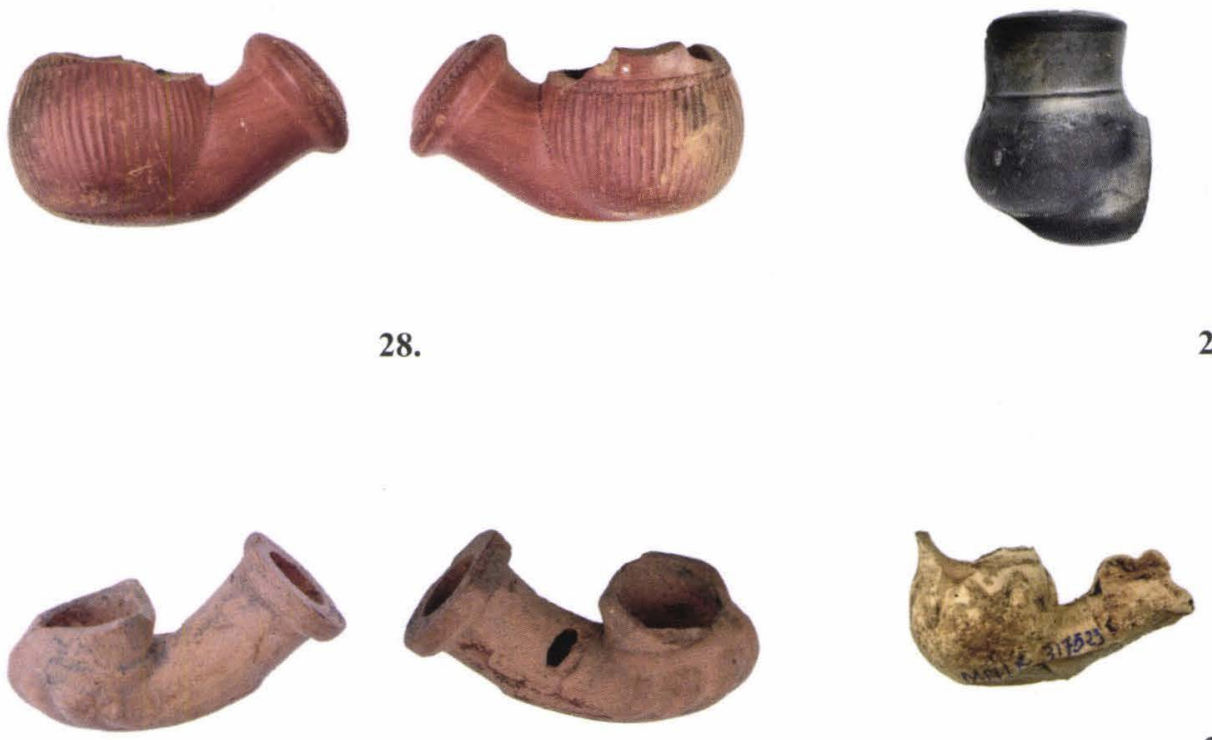

30.

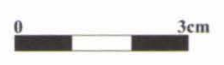

Pipe din colecția MNIR, nr. cat. 22-31

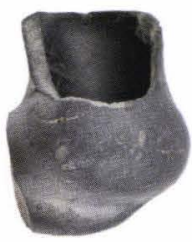

29.

23.

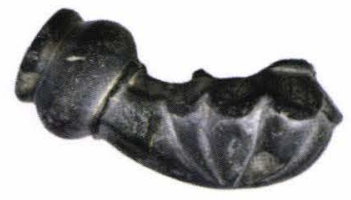

25.

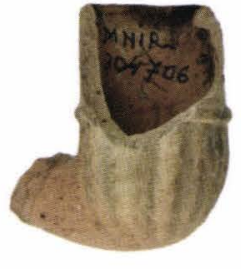

27.

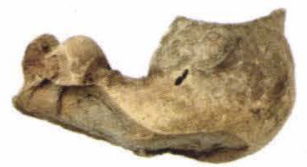

31. 
